\title{
Solutions by
}

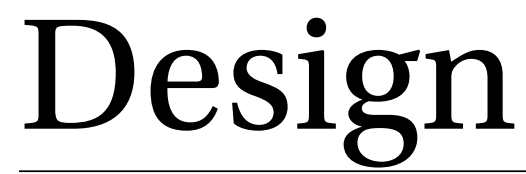

By Wednesday, Ms. Jameson had graded their latest math assessment. She shared that three students had "aced" the test. Missy smiled to herself, assuming she must be one of the top three. So, when Ms. Jameson handed her test back, Missy couldn't believe the last page was covered in red ink. Since the instructions had directed the students to show their work, Missy had only received half-credit for the correct answers to the last three questions. Instead of a perfect score, Missy was looking at a bright red $\mathrm{C}$ circled in the upper right corner of her test. Tears stung her eyes as she held them back and calculated her numeric grade: Eight math questions in total. The first five were worth eight points each, and the last three were worth twenty points each, which gave her a score of 70 out of a possible 100. 


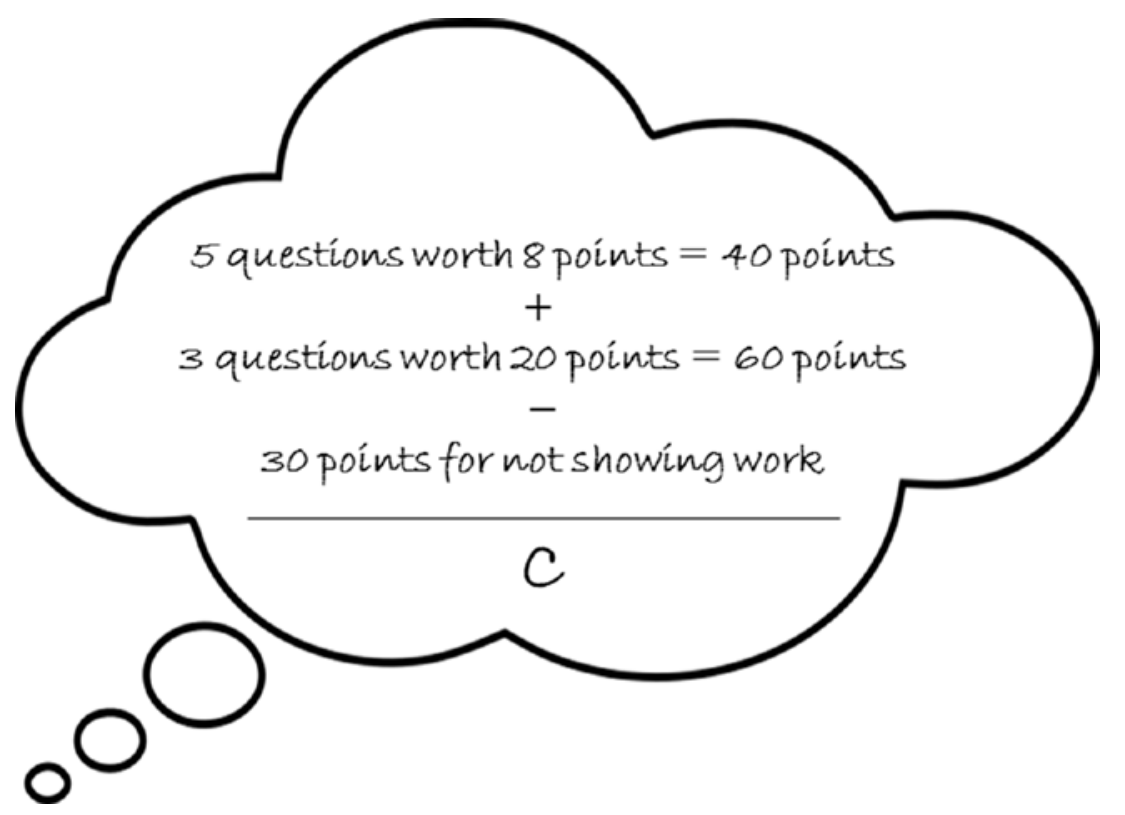

Missy could feel the heat rising from her stomach to her cheeks. She read the note from Ms. Jameson at the top of the first page telling Missy to come see her after school.

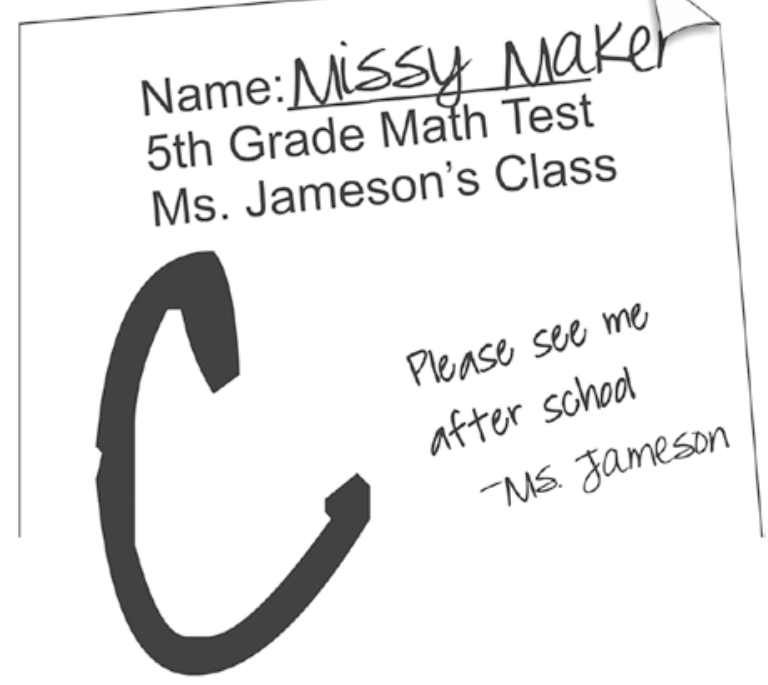


Missy tried to clear her mind by taking a deep breath. She was torn. On the one hand, she didn't want to be known as the geeky girl who always did well in math. She still really wanted to get away completely from the "Missy-MathMaker" nickname from elementary school; someday, she hoped to be known as Missy Maker-Fashionista. Maybe doing poorly on a math test was not so terrible after all. Maybe this was the year she would ditch that mean "MissyMath-Maker" moniker once and for all. So, why did she feel like such a failure?

At lunch, most students were talking about the upcoming basketball game including Missy's friends. Missy wondered why so many hours were wasted reviewing the skills of star players and guessing how they would match up against the team from St. Mark's. On the other hand, the only people talking fashion were a few of the Figures and Icons club members; similarly, Missy only heard one passing remark about the Math Olympics where Peter was projecting a shut-out for the CHAPS team.

Missy looked for AJ in the crowded cafeteria. When she couldn't find her, Missy sat with Danny and Mahdavi who cheered her up with their playful banter. Missy loved listening to the two of them talk about anything. Their unique accents were captivating. The two discussed their roles in the CHAPS Marching Band. They reviewed the marching band's playlist and the timing as they would be playing both before the big game and ahead of the math meet to get everyone stoked up. Danny played the trumpet and Mahdavi performed with the color guard. They discussed the band's marching routines and concluded that the whole event would be great fun, if not a little crazy because of the double-booking. The Math Olympics competition was scheduled to follow the basketball game. The two events were being held back-to-back on the CHAPS campus. Mahdavi passed Missy a sketch she and Danny had worked on that included a new idea for their school logo and a redesign of the marching band uniforms.

"Wow. These are so great," Missy commented.

Toward the end of lunch, $\mathrm{A}$ s slid in and squeezed next to Missy on the cafeteria bench. Her eyes were red and puffy. It looked as if she had been crying, though she kept her head down and focused on unwrapping her lunch.

"You OK?" Missy asked in a hushed voice so no one would overhear. Danny and Mahdavi continued chatting away and didn't seem to notice that AJ had joined their table.

"Yeh. I'm fine," AJ answered finally releasing a granola bar from its packaging, hoping to eat it before the bell rang.

"You don't look fine," Missy pressed.

"I don't want to talk about it now," AJ said stuffing a bite of granola into her mouth just as the bell rang. 


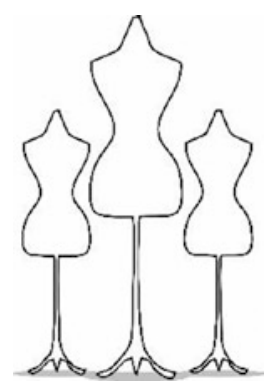

All afternoon, Missy dreaded her meeting with Ms. Jameson. How could she explain what happened? How would a teacher ever understand the strange problem Missy had? How weird was it that she loved math but didn't want anyone to know about it? Her classes went by in a daze, and at 3 PM, she gathered her books and stopped by her locker to pack up for the night, then headed to Ms. Jameson's room.

Missy was surprised to see Megan and Kim coming out just as she was entering. They exchanged quick greetings and Megan gave Missy a thumbs-up as she pulled the door closed on her way out. Missy guessed they had talked to Ms. Jameson about the bullying situation. Missy was glad she had helped them in some small way.

"Hi, Missy." Ms. Jameson said and directed her to join her at the round table next to her desk. Missy shuffled over and sat down heavily, dropping her backpack to the floor.

"Hi," Missy replied and looked down at the table in front of her.

"So," Ms. Jameson started,"it looks like you had some trouble on the test this week."

"Uh," Missy could not find any words. She fidgeted with her hands for something to do.

"It's clear that you're a very smart girl. I know you can do these math problems. After all, you did get all the answers correct. You just did not follow the clearly stated directions." Ms. Jameson paused to give Missy time to comment. When Missy remained silent, she continued,"I could not give you full credit when you didn't show how you worked through those complex problems. It's great that you arrived at the correct answers, but I have no way of knowing HOW you got there. Do you understand?"

"Yes," Missy said without looking up. She could feel heat rising from her stomach and tears filling her eyes again. She thought she might cry if she said any more. So, she kept her eyes focused on her two hands now resting on the table. 
"Now, it's just one test. It's not going to ruin your whole year. Still, I really need to see your work. You need to show how you are addressing the problem and what math concepts you are applying. OK? I need to see that you are not just guessing."

“OK," Missy said still staring at her hands.

"Please look at me," Ms. Jameson said.

That was all it took, as Missy turned her gaze from her hands to Ms. Jameson, the tears started flowing. "OK. I get it. I do. I just lost track of the time. I did all the math in my head and just wrote down my results. I knew I should show my work, but the bell already rang and you were calling for us to turn in the exams."

Ms. Jameson seemed prepared for the tears and handed Missy a tissue box. "Wow. You answered all three questions in a matter of minutes. That's amazing, Missy! You really are a gifted young lady."

Missy dabbed her eyes with the tissue then blew her nose. Right now she didn't feel very gifted, and she was out of words.

"Alright then, I know you will manage your time better and follow the directions more closely in the future. For your homework, please take the time to work through those problems again, this time showing your work and your calculations," Ms. Jameson concluded and handed Missy another tissue. "You might also consider joining the math club, kiddo. You have some special skills."

Missy shook her head at the comment. She composed herself and grabbed her backpack. She threw out her tissues in the garbage pail by Ms. Jameson's desk, then she walked to the exit. Missy took a deep breath and opened the door to find AJ standing at the ready about to knock. They exchanged looks of surprise as Missy exited and AJ entered the classroom.

"Come in, AJ," Ms. Jameson called.

Missy thought about waiting by the door, but didn't want AJ to think she was spying on her. Missy thought she would check out what the mathletes were up to and then try to catch up to AJ before getting her bus home.

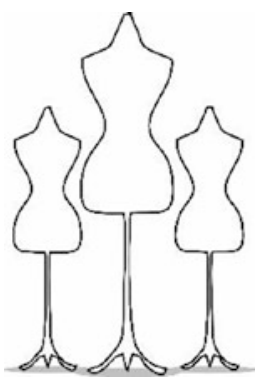


Slipping into the mezzanine of the dark auditorium was easier than Missy expected. The only lights lit up a small area on the stage where a table and five chairs stood. Eleven students spread out in the front center two rows. Missy recognized a few friends including Megan and Kim.

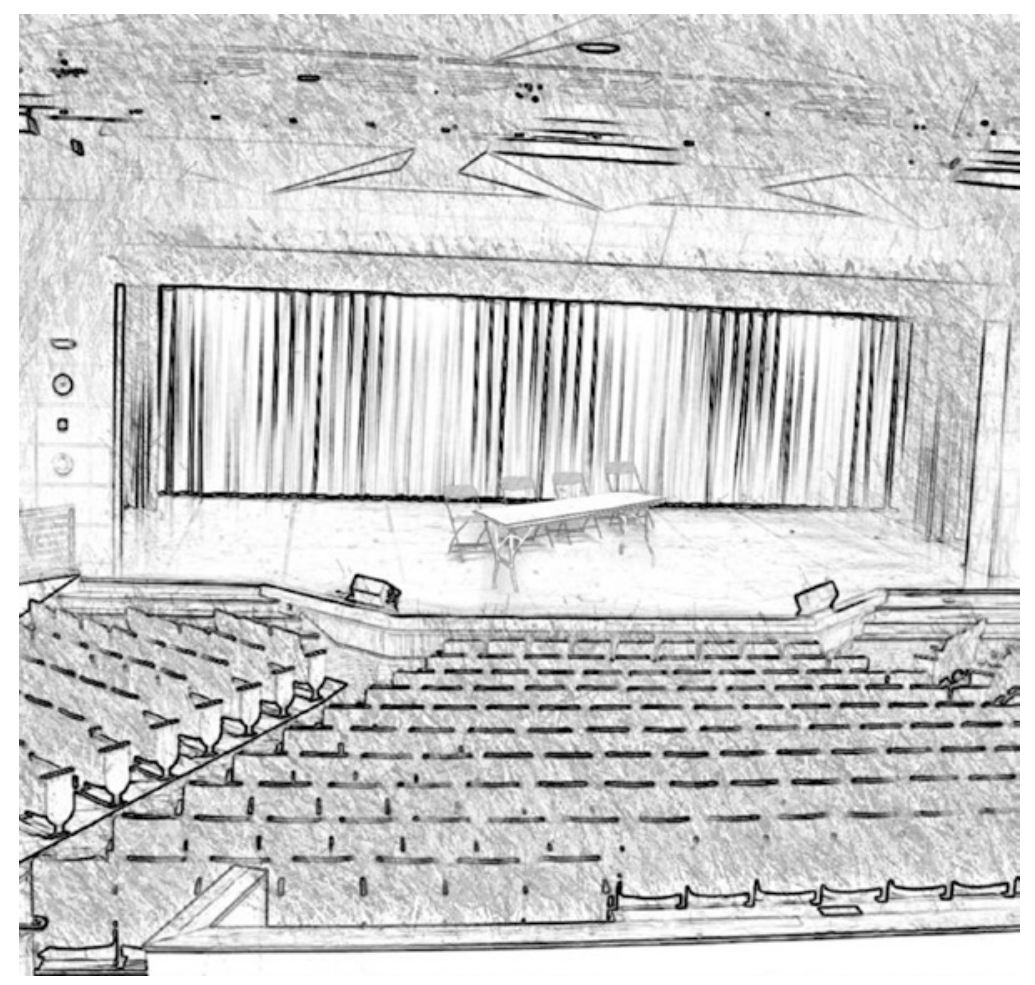

Fifty feet back from the stage and one story high, Missy wondered why she couldn't hear better as she calculated the speed of sound and the distance it would have to travel to arrive at her ears. Peter paced in front of the table on the stage. He was saying something, but from her elevation, Missy could only catch an occasional word. "Win ... Olympics ... CHAPS ..." Missy heard Peter saying.

The math team had been meeting and practicing for weeks. CHAPS was hosting the Math Olympics the next weekend. Missy had stayed away until now, but the excitement of the upcoming competition had her friends buzzing though not many people really knew what it was all about. Missy's curiosity had finally won out. She wanted to find out more. She took a seat in the second row of the mezzanine and leaned forward to see if she could hear any better. Suddenly she heard the clickety-click-squeak of a nearby door opening up. She slouched down in her seat so she wouldn't be seen. 
Christopher Jones stepped to the front of the mezzanine and waved his hands toward the people on the stage below. He shouted, "Are you talking? Totally cannot hear you up here!"

Chris was practically an icon at CHAPS. He was an eighth grader who had found his calling early with the Audio-Visual Club and managed to first convince the AV department and then the CHAPS school board to upgrade to a modern digital system. He led the efforts to fundraise for it, and he had created a CHAPS-TV channel where the AV Club members anchored school news and shared school announcements every day during homeroom. And, on top of that, Missy thought he was the cutest boy in the school!

Chris had brown eyes. Missy noticed on CHAPS-TV how they sparkled with golden highlights. His light brown hair was long and usually swept back from his face when he was on camera, but off camera it flopped across his forehead and partially hid his eyes. Missy got the sense that Chris wanted to be hiding behind his long hair. He looked to be about five and one-half feet tall, which made him about six and one-half inches taller than Missy. The perfect boy-to-girl height ratio, she imagined. Under other circumstances, Missy might have introduced herself or at least said "Hey," but as it was, she was holding her breath, trying to disappear completely and melt into the auditorium floor.

Suddenly, a high-pitched screech pierced the room, interrupting Missy's thoughts. She nearly jumped out of her crouched position. Missy covered her mouth because she thought she had gasped.

“OK!" Chris yelled."Now, Peter, turn on your mic!”

Missy saw Peter fiddle with a black box pinned on his belt. Then, "How's that? Test I-2-3. Test. Test," Peter's voice echoed through the auditorium.

"Great," said Chris turning to give a thumbs-up signal to someone who must have been above and behind Missy. "We'll get the rest of the mics on the table and then you'll be good to go."

Chris left the mezzanine and two minutes later showed up on the stage below. Missy sat up taller in her seat relieved that she had not been discovered. She took a deep breath. Missy turned to look back at who or what Chris was signaling to and noticed a light shining toward the stage from a small square hole at the back of the mezzanine. Then she saw some movement and guessed that a few students must be up there working the AV equipment. She blushed, wondering if she had been seen.

Peter returned to pacing and now Missy heard every word over the speakers. "Like I was saying, we've got a good team and with me as your leader, we'll crush this tournament!" 
Missy rolled her eyes. Peter was great at math, but winning would be a team effort. She was rooting for her friends, but Peter's comments just rubbed her the wrong way. She wondered if that's what had bothered Megan and Kim.

"Thanks, Peter," Ms. Jameson appeared below and stepped forward to climb the stairs up to the stage. "Isn't this exciting?" she asked turning toward the other students. Missy considered that Ms. Jameson's meeting with AJ must be over, but she stayed in her seat to hear some more.

"Go CHAPS!" Peter pumped his fist in the air, but the other math club members didn't seem to be as enthusiastic. Missy wondered why.

"Hmmm. I can see you're all a bit nervous," said Ms. Jameson. "No need for that! You are all great mathletes and to prove it, why don't we warm up with some times tables." She pointed to the first row at Kim and said, "Come on up, Kim! Lead us in twelves." Kim came up the stairs nearest her and made her way to the center of the stage. Chris appeared from backstage and handed her a microphone. He switched it on and she started,"Twelve, twenty-four,..." and the math club members joined in.

When Kim got to one hundred forty-four, Ms. Jameson said, "Great! Team, how are we feeling?" and the club members clapped and cheered. "OK, everyone on your feet!" The team stood up. "Peter lead us in fifteens."

Peter, happy to be back in the spotlight, shouted, "Fifteen, thirty," and the club joined in.

When they got to three hundred, Ms. Jameson said, "Perfect! Now that the mics are set up and the stage is set, let's divide into two teams and have a math scrimmage." She used her arm to divide the mathletes into two teams and they all climbed onstage, taking seats at the two tables. Ms. Jameson stood in the middle with her back to the audience.

Ms. Jameson explained that the judges and the announcer would be in the front row for the actual competition. Mathletes were allowed to have one pencil and one notecard in front of them to use as scratch paper. On the stage, a giant countdown clock would face the competitors. They would be allotted thirty seconds for each problem. In the finals, they would be given a full minute to answer the questions. Twelve teams would compete in rounds, with the winning teams advancing to the next rounds until only three teams remained. The last three teams would compete for first place.

"Let's run through a series of problems," Ms. Jameson said and began quizzing the teams, using her smartphone to time them.

Missy whispered the responses to herself seconds before the mathletes below.

"Excuse me?" a voice called from behind her. When Missy didn't respond, Chris came around and tapped her on the shoulder. She jumped. 
"Hi. Sorry," Chris said. "The mezzanine is closed. You can watch the team practice from the main auditorium," he said."By the way, how'd you get those answers so quick? I heard you answer before I heard anyone on the team respond."

Where had he come from? Missy had been so absorbed by the scrimmage, she had not heard any door opening or any footsteps approaching.

"Uh. Oh. Um," Missy stuttered, trying to find her words, suddenly feeling nauseous. "Oh. OK. Thanks," she finally said, standing up and brushing past him while nearly hitting him with her backpack. She quick-stepped her way up the aisle and out the door. She rounded the corner and ducked into the nearest girls' bathroom, leaving Chris standing in the mezzanine looking after her.

Missy stood by the bathroom sink and looked in the mirror. Her cheeks were bright red-just like the $C$ on her math test. She had splashed some water on her face when she heard a sob coming from one of the stalls.

"Hello?" Missy called out.

"M-m-missy? Is that you?" AJ replied while trying to contain her sobs.

"Oh my goodness! AJ, it's me!" Missy answered."Come out and tell me what's going on!"

AJ came out of the stall and washed her hands and face at the sink. Missy tore off some paper towels from a nearby dispenser and handed them to her friend.

"Oh, Missy! It's awful. I failed that math test. I don't know how it happened. I just panicked. I thought I knew the material. I studied so hard, but I totally flaked and I didn't even get to the last question," AJ said in a rush. "I didn't want to tell you before because I know it's so easy for you and I'm so embarrassed."

Missy pulled $\mathrm{A} J$ in for a hug and then spilled her guts. She confessed how she had lost track of time and flubbed on the last three questions. Soon the two girls were consoling each other and each began to feel better.

Suddenly AJ's face changed and she started to cry again. "But that's not the worst of it!" AJ cried. "My dad said if I can't keep my grades up, I have to drop all my extracurricular activities-including the fashion club and soccer!" AJ ended on a sob.

Missy's stomach turned. How could she keep her friend from failing? How could she help AJ stay in the fashion club and keep playing soccer?

"We can fix this!" Missy promised. "Remember last year? We met in the morning to study and worked on homework together after school? We can do that again! I can help you with math and you can help me stay focused and not get too distracted on fashion and our designs." 
AJ smiled,"You would do that for me?"

"Of course!" Missy exclaimed,"You're my best friend and my design partnerwe need each other!"

As the two exited the girls' bathroom, Missy recounted her run-in with Chris Jones. AJ raised her eyes, puckered her lips, and made kissing noises. "Love at first sight!" AJ declared and both the girls giggled.

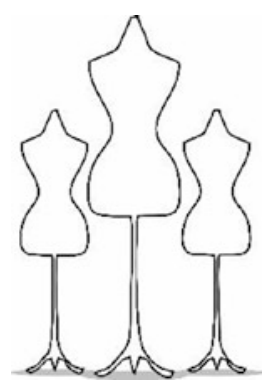

Time was not her friend these days! Missy expected to complete her designs and still get her homework done long before Dad announced "Lights out!" with finality.

This was the third night this week that she had resorted to using her smartphone to light up her textbooks under her covers. How had she gotten behind? Why was she so tired? Missy thought back to what she had been doing these last weeks. Schoolwork, house chores, helping AJ, and ... Designing! Oh designing was so much fun, and so easy to get lost in.

In her mind's eye, Missy's latest fashions high-stepped down the runway, the last one waving and entreating her forward. Missy followed the dresses, skirts and rompers across the stage and down the runway. She stopped short when she noticed that as the garments reached the end of the runway, rather than pivoting and turning back, they stepped off the edge and exploded into tiny numbers. The numbers rose up before her like a colorful plume of smoke and swirled around her making her feel shaky and dizzy. When the numbers cleared up, she saw Chris standing and applauding in the front row. One plus one equals perfection.

Missy awoke to G-ma's gentle shaking. "Wakey, wakey, Miss Melissa Merry Maker. The day's awaiting!"

Disoriented and groggy, Missy awoke and asked,"G-ma, what time is it?"

"Time to get up and start the day, dearie," G-ma said. "Your father called you twice before he left. Now you'll need to hurry if you want to catch the bus." 
Missy dressed in a fury, forgetting to check her fashion calendar or her social media feeds until she stopped by her mirror. Despite her brain fog, and racing around, Missy thought she looked pretty good. She had grabbed a pair of striped blue on blue leggings and a long gray t-shirt embellished with tiny round cut-outs on the neckline, hem and shoulders. She had experimented with a grommet-making tool and loved the effect. She added a white belt with a giant metal buckle and cinched it just below her waist. Then she tied her hair up in a quick side braid. Missy snapped a selfie and posted it with the hashtags OOTD and Never2Late4Fashion. She picked up her backpack, and ran down the stairs. G-ma handed her a granola bar as Missy passed through the kitchen and headed out the door to catch the bus to school.

Tired as she was, Missy felt like the day swept past her. Only AJ even noticed the side braid that replaced Missy's usual ponytail or pigtails. They spent lunch drilling math concepts and reviewing their tests to understand where each had made mistakes. AJ was feeling better and had signed up for extra help sessions with Ms.Jameson too. Missy was sure AJ could turn things around and be able to stay involved in her clubs and activities.

Missy had hoped to run into Chris in the hallway between classes just to say hi and to apologize for lurking in the mezzanine, but she never saw him once all day-not even on CHAPS-TV that morning. Meanwhile, all her classmates talked about was the basketball game to be held Saturday. Missy understood the excitement of an impending competition and hoped the whole school would one day be just as excited about the fashion club's meets too!

Missy returned home that evening after an extra-long homework session with AJ. She had missed the late bus and ended up walking the two-point-four miles home. She dropped her pack by the front door and snapped a selfie. Typing hashtag homeatlast and posting that with her picture, Missy climbed the five stairs from the foyer and was met by G-ma, her dad and Ms. Jameson sitting in her family's living room.

Taken aback, Missy exclaimed,"Whoa! It's not my birthday. What's going on?" Mr. Maker stepped forward. "Missy, we are here for you."

Missy stopped in her tracks. She hadn't yet told her father about her recent math test grade. She suddenly felt betrayed that Ms. Jameson had gone behind her back directly to her father. Even though she was a family friend to Missy's dad, it did not seem fair that Ms. Jameson would blab to Missy's father and then lounge on the sofa in Missy's living room.

Recognizing fear on Missy's face, Ms. Jameson quickly spoke up, "So, I ran into your dad at the supermarket this afternoon, and I mentioned that the mathletes urgently need a stand-in for our math competition on Saturday." 
Relieved on some levels, Missy sank into the recliner nearest her and kicked off her trainers nearly hitting Pi with one of them. Pi whipped Missy's legs with his tail in rebuke. Missy scooped up $\mathrm{Pi}$ and put the cat between herself and everyone else. She tucked her legs under her bottom and sat in a strange contortion on the leather rocking recliner petting Pi with her cheek as she clutched him to her chest.

"Is something going on?" Mr. Maker asked looking suspiciously from Missy to Ms. Jameson.

“Are you OK, dearie? You look a little pale," G-ma added.

Missy imagined she was being interrogated under a single bare lightbulb. In her mind, she could hear the tick-tock of an old-fashioned clock counting the seconds before her imminent doom. "Um. I don't know," Missy answered. Pi escaped Missy's grasp and jumped down to the floor."Dad, I-I was going to tell you about my math test. Then, well, with everyone here, I just thought I was in trouble or something."

"You are not in trouble!" Ms. Jameson said."But the math team is! We need a minimum of twelve people for competition. Since one student dropped out, just today, I need to find someone who can jump right in and be successful on the team. I thought of you and how quickly you can do mental math. It wouldn't be so urgent if CHAPS were not also hosting the event. Without twelve students, we will have to forfeit the competition and still host it. But, if I can find a student to join the team, we can avoid that embarrassment."

Missy resisted asking who had dropped out. Her mind wandered to her conversation with Megan and Kim. Did one of them drop out? Did the bully get called out? She pictured the two rows in the auditorium and tried to guess who from the team was gone.

"So, Missy, what do you think?" Missy's dad asked, pulling her focus back to the discussion. "I know you said you didn't want to join before. And what were you saying about a math test?"

"Oh that was nothing," Ms. Jameson supplied. "Just rushing and not reading directions. Missy and I agreed she would read and follow instructions more carefully from now on."

"Oh. So, Missy, do you think you can help the math team this weekend? It sounds like they really need you," Mr. Maker asked.

G-ma walked over to Missy and patted her shoulder. "You don't have to do this. It is your decision," she said.

Missy rocked back and forth and fidgeted with her hair considering the proposal. "I suppose I can help out this weekend, but I don't want to commit for the whole year. Is that OK?" 
Ms. Jameson clapped her hands. "Yes! That will be a huge help to the team. And, who knows, you might like it - and you would be welcome to stay on!"

One hundred percent chance of staying on the math team minus one hundred percent of interest, meant there was zero percent likelihood of joining the math club on a permanent basis. Missy promised that she would help out just this once, and Ms. Jameson explained how the competition worked and what to expect over the remaining days leading up to the event.

\section{MATH HACK: SHORTCUT FOR MULTIPLES OF I I}

For this example, let's multiply: $11 \times 75=$ ?

1. Add the digits of the number that is being multiplied by 11 .

$$
7+5=12
$$

2. Place this sum between the 7 and 5 .

$$
7 \text { ( } 12 \text { ) } 5
$$

3. If the sum exceeds 9 like it does in this case, we must carry the one over and add it to the digit on the left. In this case, that means the 7 becomes an 8 , the 2 remains in the center, and 5 is the last digit. 